\title{
Od Port Artur i Cuszimy, poprzez Sewastopol i Grodno, do Istebnej - płk dr Wacław Michał Szreders (1874-1964) jako świadek czterech wojen oraz odrodzenia i upadku Rzeczpospolitej
}

\author{
From Port Arthur and Tsushima, through Sevastopol and Grodno, \\ to Istebna - Col. Dr. Waclaw Michal Szreders (1874-1964) \\ as a witness to four wars and the revival and fall \\ of the Republic of Poland
}

\author{
Krzysztof Kopociński, Zbigniew Kopociński ${ }^{1}$
}

Żary

\begin{abstract}
Streszczenie: W latach 1795-1918, gdy Polska utraciła niepodległość i była okupowana przez trzy ościenne państwa - Rosję, Prusy i Austro-Węgry, jedną z szans utrzymania przez Polaków swej pozycji społecznej, bądź nawet awansu, była służba wojskowa. Wielu polskich lekarzy znalazło się w szeregach armii zaborczych, gdzie mimo indoktrynacji nie tracili swej tożsamości i pozostawali wierni prawdziwej ojczyźnie. Jedną z takich osób był płk dr Wacław Michał Szreders (1874-1964), w roku 1898 absolwent Cesarskiej Akademii Wojskowo-Medycznej w Petersburgu. Uczestnik wojny rosyjsko-japońskiej 1904-1905, był ordynatorem na statku szpitalnym „Kostroma” w składzie 2. Eskadry Floty Oceanu Spokojnego idącej z odsieczą dla oblężonej twierdzy Port Artur. W czasie słynnej bitwy morskiej pod Cuszimą dostał się do japońskiej niewoli. Przez kolejne lata służył w rosyjskim Szpitalu Marynarki Wojennej Floty Czarnomorskiej w Sewastopolu, gdzie osiagnął godność Naczelnego Lekarza tej placówki. Od 1918 roku w Wojsku Polskim, brał udział w wojnie polsko-bolszewickiej w 1920 roku. W okresie dwudziestolecia międzywojennego był Szefem Sanitarnym Okręgu Korpusu nr III w Grodnie. Po zakończeniu II wojny światowej przez kilkanaście lat pracował jako ordynator Państwowego Sanatorium Przeciwgruźliczego dla Dzieci i Młodzieży w Istebnej. Jego biografia jest doskonałym przykładem wykorzystywania wszelakich możliwości rozwoju zawodowego i osobistego w każdych warunkach społeczno-politycznych, nawet tych najtrudniejszych, jednak bez przekraczania granicy utraty własnej tożsamości i z zachowaniem swego systemu wartości.
\end{abstract}

Abstract: In the years 1795-1918, when Poland lost its independence and was occupied by three neighboring countries - Russia, Prussia and Austria-Hungary, one of the chances for Poles to maintain their social position or even promotion was the military service. Many Polish doctors joined the

1 105. Kresowy Szpital Wojskowy z Przychodnią SPZOZ w Żarach. Adres do korespondencji: dr n. med. Zbigniew Kopociński, 105. Kresowy Szpital Wojskowy z Przychodnią SPZOZ, 68-200 Żary ul. B. Domańskiego 2, tel. 68-470-78-62, e-mail: zkopocinski@wp.pl 
occupation armies, where, despite indoctrination, they did not lose their identity and remained faithful to the real homeland. One of such persons was Col. Dr. Waclaw Michal Szreders (1874-1964), who graduated from the Imperial Military and Medical Academy in St. Petersburg in 1898. Participant of the Russian-Japanese war of 1904-1905, he was a doctor on the hospital ship "Kostroma" from the 2nd Squadron of the Pacific Fleet going to the relief for the besieged fortress of Port Arthur. During the famous sea battle at Tsushima he got Japanese captivity. For many years he served in the Russian Navy Hospital of Black Sea Fleet in Sevastopol, where he achieved the rank of Supreme Doctor of this institution. From 1918 he was in the Polish Army and took part in the Polish-Bolshevik war in 1920. During the interwar period, he was the Head of Medical Services of the Corps District No. III in Grodno. After the end of World War II, for several years he worked as the head of the State Sanatorium for Children and Youth with tuberculosis in Istebna. His biography is a perfect example of using all possibilities of professional and personal development in all socio-political conditions, even the most difficult ones, but without crossing the border of losing identity and keeping his system of values.

Słowa kluczowe: Wacław Szreders, lekarz wojskowy, Flota Czarnomorska, Grodno, Istebna Keywords: Wacław Szreders, military physician, Black Sea Fleet, Grodno, Istebna

\section{Wprowadzenie}

Służba polskich lekarzy w armiach państw zaborczych - Rosji, Prus i Austro-Węgier - jest tematem, który nie zyskał do tej pory szerokiego zainteresowania badaczy. Może to wynikać z faktu pewnej dwuznaczności, którą niosło ze sobą robienie kariery we wrogim, okupacyjnym wszak wojsku. Nie znając całego złożonego kontekstu historycznego, można byłoby błędnie uznać wszystkich polskich oficerów na służbie państw zaborczych za ,judaszy” czy „sprzedawczyków”, którzy jedynie dla kariery lub z chciwości przypochlebiają się naszym ciemiężcom i przyczyniają do utrwalania stanu braku suwerenności a nawet ich ekspansji terytorialnej. Jednak należy patrzeć nieco szerzej, by dostrzec również pozytywne strony tego zjawiska. Pod zaborami nie istniało Wojsko Polskie, toteż nie było możliwości szkolenia militarnego siły narodowej. Lukę tę można było wypełnić właśnie służąc w armiach zaborczych, w najlepszych akademiach wojskowych zdobywając niezbędną wiedzę i doświadczenie, które w sprzyjających warunkach można byłoby wykorzystać do walki o niepodległość ojczyzny. Zwycięska wojna Polski z Rosją w 1920 roku czy Powstanie Wielkopolskie są niezbitym dowodem słuszności takiego myślenia, gdyż wygrali je żołnierze dowodzeni przez polskich oficerów wywodzących się właśnie z armii zaborczych. W przypadku polskich lekarzy na obcej służbie posądzenia o jakąś formę kolaboracji z okupantem są tym bardziej chybione, że głównym zadaniem medyków armijnych jest niesienie pomocy rannym i chorym żołnierzom, często także ludności cywilnej, co pośrednio wpływa oczywiście na gotowość bojowa jednostek wojskowych, ale nie wiąże się z czynnym i bezpośrednim udziałem $\mathrm{w}$ walkach, a jest obowiązkiem każdego doktora. Należy także mieć na uwadze, że pod zaborami wychowało się kilka pokoleń Polaków, którzy w takiej mało komfortowej sytuacji musieli sobie jakoś radzić i przystosować się w taki sposób, aby nie utracić tożsamości narodowej. Dobra posada, zapewniająca godziwe wynagrodzenie, była również formą obrony drobnej szlachty przed pauperyzacja, co szczególnie na Kresach Wschodnich w dobie repre- 


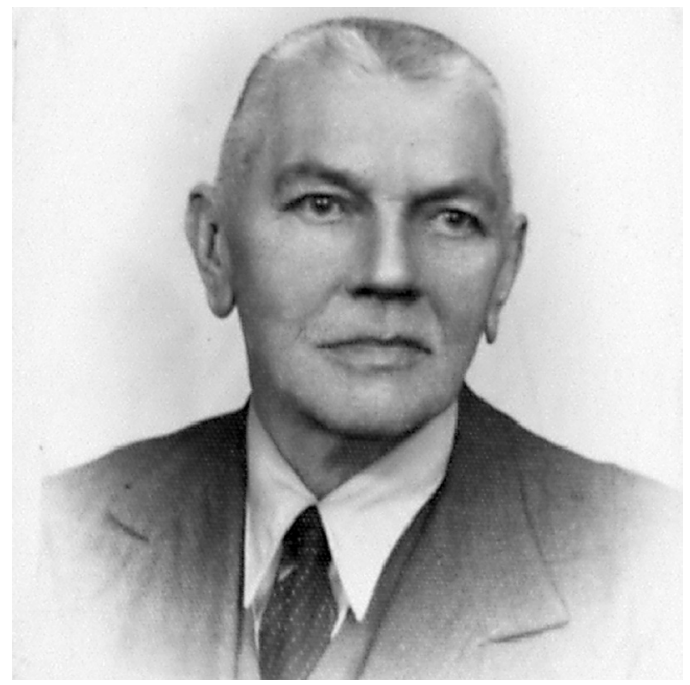

Ryc. 1. Płk dr Wacław Michał Szreders (1874-1964), fotografia z przełomu lat 1930/1940 (udostępniona dzięki uprzejmości Głównej Biblioteki Lekarskiej: KOL W. Szreders)

sji po powstaniach narodowych było realna groźbą. Studia medyczne na koszt państwa w zamian za zobowiązanie odsłużenia później co najmniej kilku lat $\mathrm{w}$ armii to pomysł, który do chwili obecnej z powodzeniem sprawdza się w wielu krajach jako doskonały sposób pozyskiwania kadr wojskowej służby zdrowia, a będący znakomitą możliwością rozwoju zawodowego szczególnie dla tych najbiedniejszych. Wielu polskich lekarzy ukończyło w ten sposób studia w ówczesnej Rosji (w Petersburgu, Wilnie, Kijowie), wstapiło do armii i stopniowo awansowało, co wiązało się z wyższymi poborami, statusem i skutkowało tym, że znaczna część z nich podejmowała decyzję o pozostaniu w wojsku na stałe. Dobrym przykładem tego typu kariery sa losy życiowe dr. Wacława Michała Szredersa, polskiego medyka na służbie carskiej na przełomie XIX i XX wieku².

\section{W Marynarce Wojennej Imperium Rosyjskiego}

Wacław Michał Szreders urodził się 28 września 1874 roku w miejscowości Birże w ówczesnej guberni witebskiej, w szlacheckiej rodzinie Donata i Ludwiki z domu Petryżyckiej. Ziemie te znajdowały się wówczas pod zaborem rosyjskim, jednak tutejsi Polacy mimo upływu wielu lat od utraty niepodległości nie zapominali o swej ojczyźnie. W momencie wybuchu powstań narodowych brali w nich czynny udział, jednym

2 A. Magowska, Życie codzienne polskich lekarzy w stużbie Rosji w XIX w. w świetle ich listów, „Kwartalnik Historii Kultury Materialnej", 2013, R. 61, nr 3, s. 423-434. 
z żołnierzy insurekcji 1863 roku był dziadek przyszłego medyka, Michał Szreders, po którym wnuk otrzymał drugie imię. Ich rodzinną miejscowość rozsławił na kartach Trylogii Henryk Sienkiewicz, który właśnie Birże wybrał jako miejsce niedoszłej kaźni wiernych ojczyźnie żołnierzy (Michała Jerzego Wołodyjowskiego, Onufrego Zagłoby i innych), którzy na rozkaz zdrajcy księcia Janusza Radziwiłła, pod eskortą niezbyt lotnego Rocha Kowalskiego, mieli być tam odesłani a następnie zgładzeni przez Szwedów. W młodzieńczych latach W. Szreders przebywał także przez pewien czas w Dyneburgu, następnie przeniósł się do Petersburga, gdzie w 1893 roku ukończył gimnazjum. Rodzina, którą objęto represjami w związku z udziałem w powstaniu, była mocno zubożona i zagrożona zupełną pauperyzacja. Jedyną możliwością dalszego rozwoju i zapewnienia sobie wsparcia finansowego ze strony państwa było podjęcie decyzji o wstapieniu do służby wojskowej bądź studia w jednej z wojskowych uczelni. Wacław Szreders w 1893 roku został słuchaczem Cesarskiej Akademii Wojskowo-Medycznej w Petersburgu, która ukończył 10 października 1898 roku uzyskując dyplom lekarza cum eximia laude, po czym powołano go do służby w Marynarce Wojennej Imperium Rosyjskiego ${ }^{3}$. Bezpośrednio po studiach miał możność pracować jeszcze przez rok w Szpitalu Dziecięcym Księcia Piotra Oldenburskiego w Petersburgu, gdzie zdobywał doświadczenie z zakresu leczenia chorób dzieci pod okiem znakomitego pediatry i laryngologa prof. Carla Gottlieba Rauchfussa (1835-1915). W dniu 11 sierpnia 1902 roku został mianowany asesorem kolegialnym (wówczas odpowiednik porucznika a od 1911 roku kapitana floty, zaś majora wojsk lądowych), w roku następnym objał funkcję młodszego lekarza 29. Flotylli Morskiej w Sewastopolu, legendarnym mieście rosyjskich marynarzy. $\mathrm{W}$ czasie wojny japońsko-rosyjskiej z lat 1904-1905 został przydzielony do 2. Eskadry Floty Oceanu Spokojnego pod dowództwem admirała Zinowija Pietrowicza Rożestwieńskiego (1848-1909) idącej z odsieczą dla oblężonej twierdzy Port Artur. Wacław Szreders objął funkcję ordynatora na statku szpitalnym Czerwonego Krzyża o nazwie „Kostroma” wchodzącym w skład oddziału kontradmirała Mikołaja Iwanowicza Niebogatowa (1849-1922). W tym czasie służba sanitarna 2. Eskadry dysponowała dwoma okrętami szpitalnymi „Angara” i „Kazań” oraz trzema statkami szpitalnymi Czerwonego Krzyża „Kostroma”, „Orzeł” i „Mongolia”. „Kostroma” to parowiec dysponujący wówczas 198. kojami dla rannych i chorych, oddziałem gangrenowym na 4 koje oraz izolatorem dla chorych zakaźnie z 10. kojami. Kapitanem tego statku był pułkownik N. W. Smielski, zaś personel medyczny tworzyli: naczelny lekarz, czterech ordynatorów, farmaceuta, 10 sióstr miłosierdzia, 5 felczerów i 10 sanitariuszy. Funkcję naczelnego lekarza sprawował radca stanu Wiktor Płotnikow, zaś ordynatorami byli: asesor kolegialny Wacław Szreders, radca dworu Paweł Gurbicz, radca dworu Józef Bilwajs, asesor kolegialny Paweł Bodiański. Rosjanie nie zdołali uratować oblężonej twierdzy Port Artur, ponieśli gigantyczną klęskę w bitwie morskiej pod Cuszimą 27-28 maj 1905 roku (wg kalendarza juliańskiego

\footnotetext{
Centralne Archiwum Wojskowe (dalej CAW), AP-9103; P. Szarejko, Stownik lekarzy polskich XIX wieku, Warszawa 1997, t. IV, s. 378-379; H. Sienkiewicz, Potop, Wrocław-Warszawa-Kraków 1991, s. 395, 419, 425 .
} 
14-15 maj 1905). Statek Szpitalny „Kostroma” został już w dniu 27 maja 1905 roku przejęty przez japoński krążownik "Sado-Maru” i odprowadzony do Sasebo, załoga wraz z lekarzami, w tym W. Szredersem, wzięta do niewoli. Konwencja Haska z 1899 roku zapewniała swobodę działania zakładów szpitalnych, jednak władze japońskie, ze względu na obecność na pokładach uzbrojenia i pododdziałów wojskowych, tylko „Kostromę" i „Mongolię" uznały za statki szpitalne i wypuściły z niewoli, pozostałe trzy jednostki zostały na stałe zarekwirowane i w dalszych latach pływały już pod japońską bandera. W dniu 14 lipca 1905 roku W. Szreders wraz z cała załoga powrócił do portu w Odessie. W nagrodę za dzielną i ofiarną służbę podczas działań wojennych został oddelegowany do Cesarskiej Akademii Wojskowo-Medycznej w Petersburgu celem podjęcia pracy naukowej, $\mathrm{z}$ dniem 16 września 1906 roku awansowany na radce dworu (odpowiednik kapitana II rangi we flocie, w wojskach lądowych podpułkownika) oraz odznaczony Orderem Św. Anny z Mieczami trzeciej klasy (15 styczeń 1907 rok za uczestnictwo w boju z flota japońska w dniach 14 i 15 maj 1905 rok). Tytuł doktora medycyny uzyskał na podstawie rozprawy pt. „Опухоли у рыб. Материалы для справнительной патологи" (Guzy u ryb. Materiały do porównawczej patologii) w dniu 22 grudnia 1907 (dyplom nr 9394), po czym powrócił do Sewastopola, gdzie objał stanowisko ordynatora tamtejszego Szpitala Wojskowego Marynarki Wojennej. W dniu 2 stycznia 1912 roku został awansowany na radcę kolegialnego (odpowiednik kapitana I rangi we flocie, w wojskach lądowych pułkownika), jako starszy lekarz Floty Czarnomorskiej pełnił obowiązki starszego ordynatora i kierownika pracowni chemiczno-bakteriologicznej Szpitala Wojskowego Marynarki Wojennej w Sewastopolu. W owym okresie jego zainteresowania medyczne ogniskowały się wokół problematyki chorób wewnętrznych oraz diagnostyki chorób zakaźnych, swoje obowiązki wykonywał jako lekarz terapeuta (internista) i bakteriolog. Niedługo przed wybuchem rewolucji październikowej, w dniu 29 września 1917 roku został mianowany radcą stanu (dawniej odpowiednik kapitana komandora, ranga poniżej kontradmirała, w wojskach lądowych pułkownik z zadatkiem na generała). W styczniu 1918 roku wyznaczono go na stanowisko inspektora sanitarnego Portu w Sewastopolu a jednocześnie naczelnego lekarza Szpitala Wojskowego Marynarki Wojennej w tym mieście. Była to już ostatnia funkcja, jaką pełnił W.Szreders w mundurze rosyjskiego marynarza, będąca jednocześnie ukoronowaniem jego służby w Marynarce Wojennej armii carskiej. W marcu 1918 roku otrzymał trzymiesięczny urlop zdrowotny i wyjechał do swej prawdziwej ojczyzny ${ }^{4}$.

4 Archiwum Wojewódzkiego Centrum Pediatrii „,Kubalonka” w Istebnej (dalej AWCPK), Akta personalne W. Szredersa; CAW, AР-9103; П. Ф. Гладких, Медицинская служба русской армии в русско-японской войне 1904-1905 г2., „Медико-биологические и социально-психологические проблемы безопасности в чрезвычайных ситуациях", 2016, n 3, s. 5-17; Классные медицинские чины Черноморского Флота <http:www.wap.kortic.borda.ru/ ?1-17-90-00000022-000-10001-0>, dostęp z 4 luty 2018 r.; Белые Корабли <https: / titanicanatomy.wordpress.com / 2016/12/07 / белые-корабли-госпитальные-суд> dostęp z 4 luty 2018. 


\section{W Wojsku Polskim podczas wojny z Rosją bolszewicką i w okresie dwudziestolecia międzywojennego}

Wacław Szreders powrócił do Polski w momencie, gdy decydowały się losy niepodległości naszego kraju. Kończąca się I wojna światowa przyniosła ojczyźnie niezwykle wprost szczęśliwy zbieg wydarzeń politycznych. Państwa zaborcze - Austro-Węgry, Prusy i Rosja - poniosły klęskę w tym konflikcie, monarchia Cesarza Franciszka Józefa (1830-1916) rozpadła się, dumni Prusacy musieli kapitulować przed Ententa, zaś Rosję ogarnęła fala krwawej i dzikiej rewolucji bolszewickiej. W. Szreders, mimo wielu lat rusyfikacji, jakiej podlegał $\mathrm{w}$ rosyjskich placówkach oświatowych i podczas służby $\mathrm{w}$ carskiej armii, nadal pozostał polskim patriota. W momencie tworzenia odrodzonego Wojska Polskiego natychmiast wstapił w jego szeregi, mimo że początkowo nie uznano jego stopnia wojskowego z armii carskiej (odpowiednik pułkownika), kwalifikując go jako kapitana i z dniem 16 grudnia 1918 roku przydzielając na stanowisko prosektora anatomii patologicznej Szpitala Ujazdowskiego w Warszawie, do stopnia majora został awansowany dopiero 20 grudnia 1919 roku jako asystent oddziału anatomii patologicznej Wojskowej Rady Sanitarnej. W czasie największego nasilenia działań zbrojnych wojny polsko-bolszewickiej objął dowództwo Szpitala Wojskowego w Żyrardowie na 500-1000 łóżek, którą funkcję sprawował w okresie 12 marzec 1920 roku - 15 marzec 1921 roku, w tym czasie został awansowany do stopnia podpułkownika (24 czerwiec 1920 r.). Za czynny i pełen poświęcenia udział w wojnie 1920 roku został odznaczony Krzyżem Walecznych nr 56012. Po zawarciu traktatu pokojowego i rozpoczęciu demobilizacji objął funkcję Przewodniczącego Stałej Lekarskiej Komisji Rewizyjnej Dowództwa Okręgu Generalnego Warszawa, która sprawował do 14 kwietnia $1921 \mathrm{roku}$. Do stopnia pułkownika awansowany 24 kwietnia $1921 \mathrm{roku}$, ostatecznie zatwierdzony w tym stopniu ze starszeństwem z dnia 1 czerwca 1919 roku. Przez kolejne kilka miesięcy (16 sierpień 1921 r. - 3 grudzień 1921 r.) był zastępcą komendanta Szpitala Ujazdowskiego w Warszawie i krótkotrwale kierownikiem Rejonu Sanitarnego nr 1 (3 grudzień 1921 - 10 styczeń 1922). Następnie skierowano go na Kresy Wschodnie, gdzie objął funkcję Szefa Sanitarnego Dowództwa Okręgu Korpusu nr IX w Brześciu nad Bugiem (DOK IX). Miasto to było wówczas siedzibą dużego garnizonu wojskowego i słynnej twierdzy, gdzie stacjonował Szpital Wojskowy nr IX. W czasie wojny z bolszewikami funkcjonowało tam kilka wojskowych zakładów leczniczych, w tym m.in. Szpital Obozu Warownego, Szpital Epidemiczny nr 1 Wojska Polskiego, Szpital Epidemiczny nr 2 Wojska Polskiego dla Jeńców, Szpital Stacji Rozdzielczej dla Jeńców. Udzielano tam pomocy nie tylko rannym, ale także chorym, gdyż w tym okresie szalały na kresach epidemie groźnych chorób zakaźnych: duru plamistego, czerwonki, grypy hiszpanki i innych. Zadaniem nowego Szefa Sanitarnego było sprawne przeprowadzenie demobilizacji wojskowych zakładów leczniczych oraz utworzenie właściwych podstaw organizacyjnych wojskowej służby zdrowia okręgu na czas pokoju. Ważnym wyzwaniem było również ostateczne rozprawienie się z ogniskami epidemii duru plamistego, którego ofiara padł m.in. komendant Szpitala Załogi Twierdzy Brześć ppłk dr Eugeniusz Karchezy. Wielkim wsparciem dla W. Szredersa był w tym czasie komendant Szpitala Okręgowego nr IX płk dr Jan Krusiewicz (1873-1930), zna- 
komity organizator i lekarz, również były oficer armii carskiej, z którym razem służył przez pewien czas w Sewastopolu ${ }^{5}$.

Kolejnym kresowym miastem, z którym przez pewien czas związał swój los płk dr W. Szreders, było Grodno. W dniu 24 października 1922 roku wyznaczono go na stanowisko Szefa Sanitarnego DOK III. Był to jeden z dziesięciu wówczas funkcjonujących okręów, niezwykle ważny ze względu na swoje nadgraniczne położenie, którego wojskowa służba zdrowia dysponowała aż dwiema, co było rzadkością, dużymi stacjonarnymi placówkami leczniczymi: 3. Szpitalem Okręgowym w Grodnie i Szpitalem Obszaru Warownego Wilno w Wilnie. Było to prawdziwe bogactwo, z którego wojskowy sanitariat sprawnie korzystał nawiązując współpracę z Wydziałem Lekarskim Uniwersytetu Stefana Batorego, co procentowało podnoszeniem poziomu zawodowego i kwalifikacji lekarzy wojskowych III. Okręgu Korpusu a jednocześnie było korzystne także dla uczelni, która mogła rozlokować część klinik na terenie Szpitala Obszaru Warownego Wilno. Podobnie znana była grodzieńska lecznica wojskowa, ciesząca się dużym prestiżem i uznaniem w całym regionie. Szefowi Sanitarnemu DOK III, poza szpitalami, podlegało także trzech kierowników Rejonów Sanitarnych: Grodno (ppłk dr M. Montrym-Żakowicz), Lida (płk dr L. K. Klott), Wilno (płk dr W. Kiersnowski) oraz 3. batalion sanitarny z Grodna. Widać zatem, że na barkach W. Szredersa spoczywało dużo obowiązków, lecz na szczęście miał znaczące wsparcie zaufanego grona współpracowników w szefostwie, w tym m.in.: mjr. dr. Stanisława Orłowskiego, mjr. dr. Mieczysława Kolendo, mjr. apt. Stanisława Sosnowskiego, kpt. san. Ksawerego Wierzbowskiego. Przy właściwej obsadzie kadry kierowniczej poszczególnych instytucji podlegających szefostwu, można było dobrze i sprawnie zorganizować cały system funkcjonowania wojskowego sanitariatu w okręgu, co niewattpliwie udało się dr. Szredersowi i było jego dużym sukcesem ${ }^{6}$.

Przywiązywał on także dużą wagę do właściwego działania Wojskowego Szpitala Sezonowego w Druskiennikach (filii 3. Szpitala Okregowego), który funkcjonował od 1926 roku i cieszył się wielką renomą wśród kadry oficerskiej i rodzin wojskowych. Druskienniki, jako kurort, były też ulubionym miejscem wypoczynku marszałka Józefa Piłsudskiego, toteż Szef Sanitarny DOK III musiał mieć wówczas na uwadze dobre zorganizowanie pracy tego ośrodka. Niewatpliwie odniósł w tym zakresie znaczacy sukces, do czego w dużej mierze przyczyniła się kadra lekarska grodzieńskiej lecznicy wojskowej. Z całą pewnością był dobrym organizatorem i sprawdzał się w roli szefa dużej instytucji, potrafił nawiązywać i utrzymywać dobre kontakty z podległa kadra oficerska, przy zachowaniu odpowiedniego dystansu i poszanowaniu wymogów

\footnotetext{
5 CAW, AP-9103; Z. Kopociński, K. Kopociński, Cz. Jeśman, Płk dr Jan Józef Krusiewicz (1873-1930) twórca i pierwszy komendant 9. Szpitala Okręgowego w Brześciu nad Bugiem, "Lekarz Wojskowy”, 2016, t. 94, nr 4, s. 456-460; K. Kopociński, Z. Kopociński, Zarys organizacji i działalności 9. Szpitala Okregowego w Brześciu nad Bugiem w latach 1920-1939, "Archiwum Historii i Filozofii Medycyny”, 2010, t. 73, s. 46-48.

6 A. Felchner, Pod znakiem Eskulapa i Marsa. Stużba Zdrowia Wojska Polskiego (od jesieni 1918 r. do mobilizacji w 1939 r.), Oświęcim 2016, s. 246-247, 250; K. Michejda, Wspomnienia chirurga, Kraków 1986, s. 212-216, 229-231; Z. Kopociński, K. Kopociński, Cz. Jeśman, 75. rocznica likwidacji 3. Szpitala Okregowego w Grodnie-zarys historii powstania i rozwoju, "Lekarz Wojskowy”, 2015, t. 93, nr 1, s. 129-134; Rocznik oficerski 1924, Warszawa 1924, s. 47; Rocznik oficerski 1928, Warszawa 1928, s. 709-711.
} 


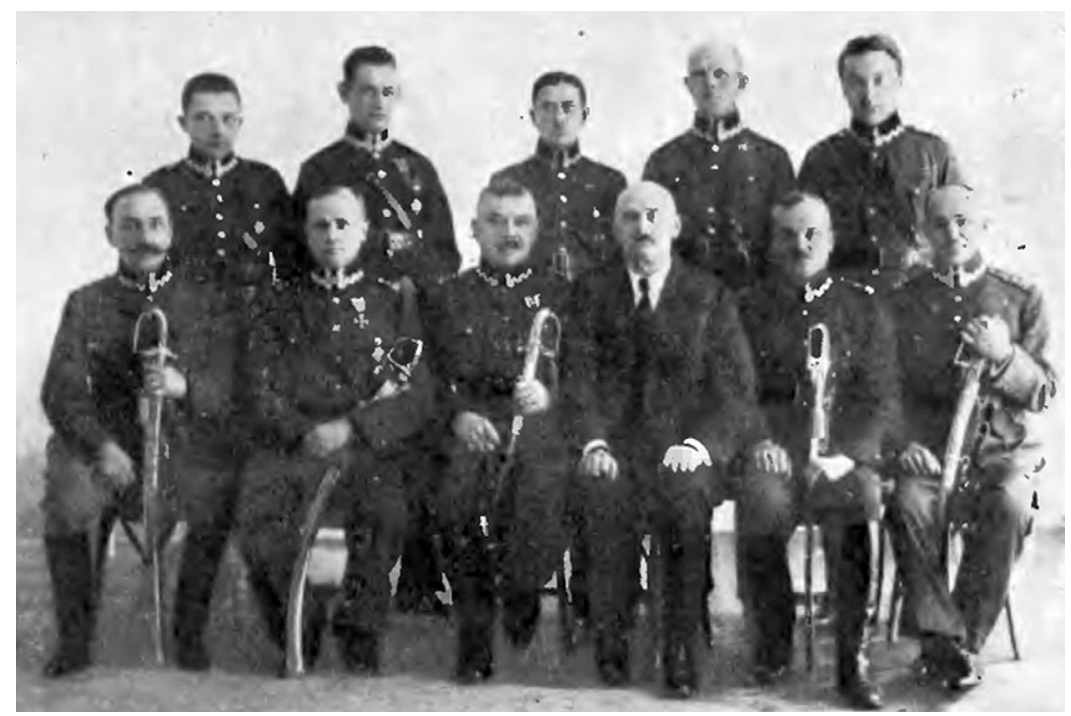

Ryc. 2. Zarząd WKS „Niemen” w Grodnie, w pierwszym rzędzie trzeci od lewej płk dr Wacław Michał Szreders, prezes i założyciel tego klubu, Grodno, 1925

(Źródło: Wojskowy Klub Wioślarski „Niemen” w Grodnie, „Wioślarz Polski”, 1925, r. 1, nr 2, s. 55)

służby. Miał też poważanie swych przełożonych i doskonałe relacje z dowódca III. Okręgu Korpusu, co procentowało podczas rozwiązywania różnego rodzaju codziennych problemów służbowych? ${ }^{7}$.

Wykorzystując pobyt w Grodnie i jego położenie nad Niemnem, W. Szreders jako wielki entuzjasta sportów wodnych, co pozostało mu zapewne z czasów służby w carskiej Marynarce Wojennej, założył w dniu 23 marca 1923 roku Wojskowy Klub Wioślarski „Niemen” (WKW) i do czasu odejścia z Grodna był jego prezesem. Uzyskał na tym polu duże wsparcie innych lekarzy wojskowych z 3. Szpitala Okręgowego, w szczególności ówczesnego starszego ordynatora oddziału skórno-wenerycznego kpt. dr. Edmunda Łakińskiego (1889-1940), który pełnił w klubie funkcję II wiceprezesa i skarbnika. Duże zdolności organizacyjne W. Szredersa sprawiły, iż w krótkim czasie oczyszczono część nabrzeża i zbudowano przystań oraz sprowadzono łodzie. W szczytowym okresie swej działalności w klubie było ponad 200. członków stałych i gości, dysponowano dziesięcioma łodziami. Prezesowi udało się zrealizować szereg bardzo ciekawych przedsięwzięć turystyczno-sportowych, w tym m.in. wodną wyprawę łodzią sportowa z Grodna do Warszawy, przez Niemen, kanał Augustowski, Biebrzę i Narew. Chyba najbardziej spektakularnym wydarzeniem było przepłynięcie Wisła z Krakowa do Gdyni, co udało się jako pierwszej w historii odrodzonej ojczyzny

7 A. Kierzek, Uzdrowiska nadniemeńskie dawniej, Wrocław 2017, s. 109-118; Z. Kopociński, Zarys historii Wojskowego Szpitala Sezonowego w Druskiennikach, „Lekarz Wojskowy”, 2004, t. 80, nr 4, s. 280-281; AWCPK, Akta personalne W. Szredersa; CAW: AP-9103. 
właśnie załodze klubu sportowego z Grodna. Ośmioosobowa grupa oficerów i podoficerów, której sternikiem był sam W. Szreders, po wielodniowym i trudnym rejsie w dniu 27 lipca 1924 roku wpłynęła na Morze Bałtyckie, czym zapisała piękną kartę w dziejach polskiego sportu wodnego. Warto zauważyć, że WKW „Niemen” (znany również pod nazwa "Grodno") posiadał także swoje filie zamiejscowe, w tym m.in. w Suwałkach czy Druskiennikach. Płk dr W. Szreders był ze swojej pasji wodniackiej powszechnie znany w mieście króla Batorego, toteż chwila rozstania $\mathrm{z}$ tym grodem była zapewne dla niego dość bolesnym przeżyciem ${ }^{8}$.

Z dniem 6 listopada 1928 roku objął funkcję kierownika pracowni statystycznej w Szkole Podchorążych Sanitarnych w Warszawie, by w następnym roku objać tam kierownictwo pracowni anatomo-patologicznej, gdzie pełnił służbę do czasu przeniesienia w stan spoczynku z dniem 28 lutego 1930 roku. W dowód uznania jego nienagannej postawy i zasług położonych na rzecz polskiej wojskowej służby zdrowia w dniu 10 listopada 1929 roku został udekorowany Złotym Krzyżem Zasługi (nr 6223). Z tego ostatniego okresu zachowała się opinia służbowa sporządzona na jego temat przez gen. bryg. dr. Stefana Hubickiego (1877-1955): „B. prawy wyrobiony charakter, b. lojalny, b. dobry oficer, b. wytrzymały fizycznie, b. dobry organizator. B. dobry prosektor, chętnie pogłębiajacy swą wiedzę fachową" ${ }^{\prime 9}$.

\section{II wojna światowa, okupacja niemiecka, nowe porządki - mała stabilizacja w Istebnej}

Po zakończeniu zawodowej służby wojskowej W. Szreders mieszkał na warszawskim Żoliborzu przy ulicy Kaniowskiej 31/1 i pracował jako zastępca naczelnego lekarza Ubezpieczalni Społecznej w Żyrardowie. Wybuch II wojny światowej przerwał tę spokojną i stabilną egzystencję. W czasie niemieckiej okupacji utrzymywał się z emerytury wojskowej, dorabiał jako lekarz Ubezpieczalni Społecznej w Warszawie. W stolicy przeżył koszmar Powstania Warszawskiego, po kapitulacji wysiedlony wraz z całą ludnością cywilna, przebywał na wsi w powiecie jędrzejowskim. Już w marcu 1945 roku powrócił do stolicy, gdzie objął w Ubezpieczalni Społecznej funkcję Naczelnego Lekarza Żoliborza. Fatalne warunki mieszkaniowe sprawiły, że opuścił swoje miasto i wyjechał daleko na południe, do malowniczo położonej Istebnej. Mała miejscowość górska z ciekawym pod względem architektonicznym sanatorium leczenia gruźlicy u dzieci i młodzieży, które w 1938 roku przyjęło nazwę Wojewódzki Zakład

W. Grzelak, Wędrówki wodne, "Wiarus”, 1933, r. IV, nr 17, s. 373-374; Z Grodna do Warszawy łodziq sportowa. Wycieczka wojskowego Klubu Wioślarskiego "Niemen”, „Polska Zbrojna”, 1923, r. III, nr 208, s. 4; Z Wojskowego Klubu Wioślarskiego "Grodno", „Sport Wodny”, 1928, r. 4, nr 3, s. 47; Wojskowy Klub Wioślarski „Niemen” w Grodnie, „Wioślarz Polski”, 1925, r. 1, nr 2, s. 54-55; Początki działalności sportowej, „Sport Wodny", 1930, r. 6, nr 3, s. 45, 86-87.

9 J. L. Englert, A. Domar Domaradzki, Szkoła Podchorażych Sanitarnych 1922-1939, Londyn 1997, s. 17; Podchorażowie z Ujazdowa. Wspomnienia Szkoty Podchorażych Sanitarnych. W 50-ta rocznice założenia Szkoły, opr. B. Markowski, Londyn 1972, s. 97; AWCPK, Akta personalne W. Szredersa; CAW, AP-9103. 
Leczniczo-Wychowawczy im. J. Piłsudskiego, była już ostatnią zawodowa przystanią byłego lekarza carskiej Marynarki Wojennej. Nie był to zapewne przypadek, gdyż funkcje dyrektora tej placówki sprawował dr Włodzimierz Leśniewski (1897-1971), także były zawodowy lekarz wojskowy, w okresie dwudziestolecia międzywojennego w stopniu majora służył w 23. Pułku Ułanów Grodzieńskich. W dniu 9 października 1945 roku W. Szreders został ordynatorem Wojewódzkiego Zakładu Leczniczo-Wychowawczego w Istebnej (w późniejszym okresie placówka zmieniła nazwę na Państwowe Sanatorium Przeciwgruźlicze dla Dzieci i Młodzieży) i wraz z żoną zamieszkał na terenie ośrodka ${ }^{10}$.

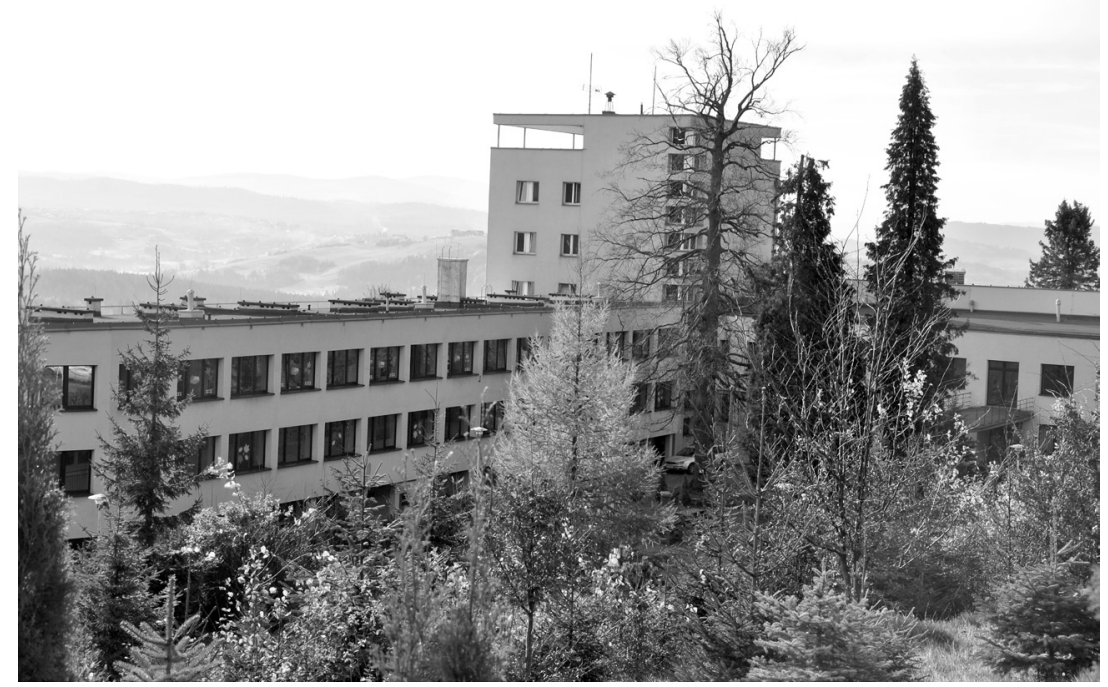

Ryc. 3. Wojewódzkie Centrum Pediatrii „Kubalonka” w Istebnej, 2018 (fot. Z. Kopociński)

Gruźlica była olbrzymim problemem społecznym już w okresie dwudziestolecia międzywojennego, gdy nasz kraj przodował w ilości zgonów wywołanych przez to schorzenie np. w 1936 roku 17,6\% w Polsce, natomiast w Anglii 5,9\% czy Włoszech 6,5\%. II wojna światowa niosąca ze sobą traumatyczne przeżycia milionów Polaków (głód, wyniszczenie, ogromny stres itp.) zaowocowała zwielokrotnieniem ilości ludzi chorych. Niestety zrujnowanie i ograbienie kraju w wyniku działań wojennych, śmierć tysięcy lekarzy i pracowników służby zdrowia, brak powszechnego dostępu do nowoczesnego leczenia (Streptomycyna i PAS były wówczas towarem deficytowym) skutkowały rozprzestrzenianiem się choroby i infekowaniem także dzieci wychowujących się w otoczeniu osób chorych i prątkujących. Walkę o zdrowie i życie

10 AWCPK, Akta personalne W. Szredersa; Główna Biblioteka Lekarska w Warszawie, KOL W. Szreders; Rocznik oficerski 1932, Warszawa 1932, s. 328, 650. 
młodych pacjentów, mimo wszelkich niedogodności i ryzyka zachorowania, podejmowali polscy lekarzy w ośrodkach zlokalizowanych na terenie całego kraju, w tym w Istebnej ${ }^{11}$.

Po ciężkich przeżyciach okupacyjnych i kilku miesiącach pobytu w zniszczonej Warszawie, był to prawdziwy azyl, choć warunki także nie były zbyt luksusowe. Warto podkreślić, że instytucja była przeznaczona do leczenia 400 dzieci, zaś zatrudniono w niej jedynie dwóch lekarzy ordynatorów, W. Szredersa i Wiktorię Nowicką (18871975), oraz dyrektora Włodzimierza Leśniewskiego. Pismo ostatniego z wymienionych, z dnia 13 lutego 1947 roku do Oddziału Personalnego Urzędu Wojewódzkiego Ślasko-Dabrowskiego z wnioskiem o podwyższenie stałej premii miesięcznej podległych mu medyków, doskonale ilustruje całą sytuację: „,...lekarze ci we dwoje obsługują 400 dzieci, spełniając w ten sposób już od 6 miesięcy robotę co najmniej 4 lekarzy. Dzięki ich niezwykle sumiennej i ofiarnej pracy poziom leczniczy Zakładu utrzymuje się na należytej wysokości, mimo wielkiego braku rąk lekarskich. Im też w znacznej mierze zawdzięcza Zakład zdobycie wśród społeczeństwa śląskiego i innych dzielnic kraju opinii, że dzieci kierowane tutaj na kurację maja zapewniona najtroskliwszą opiekę lekarską i wszystkie niezbędne warunki dla odzyskania zachwianego lub utraconego zdrowia. Poczuwam się do obowiązku zaznaczyć, że (...) lekarze mimo bardzo skromnych, w porównaniu z innymi zakładami leczniczymi, warunków płacy, dają z siebie maximum wysiłku..."12. Na przełomie lat 1947/1948 nastapiła stabilizacja obsady kadrowej placówki, dr W. Leśniewski wyjechał do Szklarskiej Poręby, gdzie rozpoczał pracę w sanatorium PKP, zaś funkcję dyrektora w Istebnej objał dr Zygmunt Dadlez (1887-1962), jeden z jej twórców i współorganizatorów w latach 1930., osoba niezwykle zasłużona dla rozwoju tego zakładu, który przyjał nazwę Państwowe Sanatorium Przeciwgruźlicze dla Dzieci i Młodzieży. Nieco wcześniej odeszła do Sanatorium w Kamiennej Górze dr Wiktoria Nowicka, po której wakat objęła dr Maria Śniegocka, na stanowisku trwał wciąż niezmiennie jedynie dr W. Szreders. Trójka lekarzy, mimo dużego obciążenia praca, zgodnie ze sobą współpracowała i dzieliła się obowiązkami. Dyrektor ośrodka bardzo szanował i cenił sobie starszego kolegę a jednocześnie podwładnego. W czasach stalinowskiego terroru W. Szreders nie taił swojego życiorysu, choć biografia carskiego marynarza i oficera "sanacyjnego wojska” były okolicznościami, które mogły być źródłem niebezpieczeństwa i stać się powodem aresztowania oraz szykan. Niewatpliwie tarczą ochronną dla niego w tamtym ponurym czasie była lojalna postawa jego współpracowników, szczególnie dyrektora Zygmunta Dadleza, który wystawiał mu zawsze znakomitą opinię wobec wyższych przełożonych, której przykładem może być ta z 14 lutego 1953 roku: „...obowiązki swoje wykonuje bardzo sumiennie; można powiedzieć cały dzień z przerwa południowa pracuje w Sanatorium bez względu na rozkład dyżurów (...) charakter posiada stanowczy, przez dzieci bardzo lubiany, w stosunku do personelu ma dobre podejście...". Wojskowy

11 K. Kopociński, Z. Kopociński, Cz. Jeśman, Sanatorium Rehabilitacyjne Leczenia Zeza w Sobótce, Żary 2016, s. 33; Maty rocznik statystyczny 1939 r., pod red. S. Szulc, Warszawa 1939, s. 302.

12 AWCP, Akta personalne W. Szredersa. 
lekarz odpłacał się pełnym poświęceniem pracy a trzeba pamiętać, że był najstarszym lekarzem w załodze placówki. Pomimo upływu lat starał się wciąż podnosić swoje kwalifikacje zawodowe i na bieżąco śledzić postępy medycyny. W 1946 roku uczestniczył w kursie przeciwjagliczym, który odbywał się w Łodzi, a służył zapoznaniu jego uczestników ze sposobami diagnostyki i leczenia jaglicy, czyli groźnej choroby zakaźnej oczu, która była wówczas znacznym problemem epidemicznym. Po czternastu latach pracy w Istebnej w dniu 25 marca 1959 roku Prezydium Wojewódzkiej Rady Narodowej w Katowicach wydało decyzję uznającą dr. W. Szredersa specjalistą drugiego stopnia z zakresu ftyzjatrii dziecięcej. Swoją pracę zawodową w służbie zdrowia zakończył w dniu 30 czerwca 1961 roku w wieku 87 lat, gdyż Ministerstwo Zdrowia, mimo prośby skierowanej przez samego zainteresowanego, nie wyraziło zgody na kontynuowanie przez niego pracy w Państwowym Sanatorium Przeciwgruźliczym dla Dzieci i Młodzieży ze względu na znaczne przekroczenie wieku emerytalnego (wówczas 65 lat). Doprawdy trudno byłoby znaleźć dzisiaj takowego lekarza, który nie z powodów materialnych, lecz dlatego że tak ukochał swą pracę i pacjentów, nie chciałby odejść na zasłużoną emeryturę. W dowód uznania jego wkładu w rozwój placówki w Istebnej dyrektor Z. Dadlez w dniu 20 kwietnia 1961 roku wystapił z wnioskiem o nadanie mu odznaki „Za Wzorową Pracę w Służbie Zdrowia”, został także uhonorowany Medalem Dziesięciolecia Polski Ludowej (1955, nr 321245)13.

Po zakończeniu aktywności zawodowej nadal pozostał w swoim mieszkaniu na terenie sanatorium, gdzie dożył końca swych dni. W życiu prywatnym tworzył udany związek małżeński z Helena z domu Stopińska, nie dochowali się potomstwa. Służba w obcej armii dała mu biegła znajomość języka rosyjskiego, słabiej posługiwał się językiem francuskim, angielskim i niemieckim. W okresie PRL był członkiem Związku Zawodowego Lekarzy i Związku Zawodowego Pracowników Służby Zdrowia, nigdy nie wstapił do żadnej partii politycznej. Po 1945 roku z krewnych utrzymywał kontakt głównie z rodzeństwem, gdyż rodzice zmarli dużo wcześniej: Donat Szreders w 1897 roku a Ludwika Szreders w 1932 roku. Młodszy brat, Jan Szreders (1876-1947), był leśnikiem, zmarł wkrótce po zakończeniu II wojny światowej. Tradycję rodzinną w zawodzie lekarza kontynuował siostrzeniec W. Szredersa, syn jego siostry Marii Aleksandrowicz, Jan Aleksandrowicz (1906-2001), także lekarz wojskowy, absolwent Szkoły Podchorażych Sanitarnych z 1935 roku, żołnierz Armii Krajowej, kawaler Krzyża Virtuti Militarii.

Płk dr Wacław Michał Szreders, lekarz, zawodowy oficer carskiej Marynarki Wojennej a następnie Wojska Polskiego, uczestnik wojny rosyjsko-japońskiej, obrońca ojczyzny w czasie wojny polsko-bolszewickiej 1920 roku, kawaler Krzyża Walecznych, zmarł 22 listopada 1964 roku na terenie sanatorium w Istebnej, w wieku 90 lat, z powodu niewydolności krążenia. Pochowany na Cmentarzu Parafialnym w Istebnej ${ }^{14}$.

Jego osobistym doświadczeniem życiowym stały się tragiczne wydarzenia czterech wojen, których był naocznym świadkiem i w różnej mierze uczestnikiem. Każdy

13 AWCP: Akta personalne W. Szredersa.

14 AWCPK: Akta personalne W. Szredersa; Główna Biblioteka Lekarska w Warszawie: KOL W. Szreders; J. L. Englert, A. Domar Domaradzki, op. cit., s. 34, 112; CAW: AP-9103. 
z kolejnych konfliktów był bardziej okrutny, bezwzględny i krwawy niż poprzedni. Przeżył chwile wielkiego tryumfu, gdy na jego oczach po 123. latach niewoli odrodziła się niepodległa ojczyzna, by następnie być świadkiem jej tragicznego upadku. Doświadczył strachu, niewoli, głodu, upokorzenia, jednak nigdy nie zatracił powołania zawodowego i chęci niesienia pomocy drugiemu człowiekowi. W jego przypadku nie był to tylko profesjonalizm i sposób zarabiania pieniędzy na życie, lecz prawdziwa pasja i głębokie umiłowanie fachu lekarskiego, który pragnął wykonywać niemal do końca swych dni. Niestety pamięć o tym wspaniałym medyku, który kilkanaście ostatnich lat życia poświęcił Państwowemu Sanatorium Przeciwgruźliczemu dla Dzieci i Młodzieży w Istebnej i swym małym podopiecznym, nie przetrwała próby czasu. Wśród współczesnych mieszkańców miejscowości prawie nikt nie kojarzy jego osoby. Z cała pewnościa sytuację tę należy zmienić i pozostawić trwały ślad pobytu i działalności w tej górskiej osadzie płk. dr. Wacława Michała Szredersa, niezwykłego lekarza i prawego człowieka. Długoletni ordynator byłego sanatorium z cała pewnością zasługuje na to, by uhonorować jego postać kamienną tablicą umieszczoną na budynku dzisiejszego Wojewódzkiego Centrum Pediatrii „Kubalonka” w Istebnej, gdzie spędził ostatnie lata swego pracowitego życia.

Marzeniem autorów niniejszej publikacji byłoby, aby upamiętnić postać płk. dr. W. Szredersa również na terenie pięknego kompleksu zabudowań 1472. Klinicznego Szpitala Marynarki Wojennej Federacji Rosyjskiej (były carski Szpital Marynarki Wojennej Floty Czarnomorskiej) w Sewastopolu, aby przypomnieć w ten sposób o dużej roli, jaką odegrali polscy lekarzy w rozwoju tego ośrodka. Oficerowie, którzy służąc $\mathrm{w}$ rosyjskiej armii i przyczyniając się do podniesienia poziomu opieki zdrowotnej Rosjan oraz rozmaitej ludności terenów okupowanych, w sercu i duszy pozostali polskimi patriotami.

Wykaz źródeł:

1. Archiwum Wojewódzkiego Centrum Pediatrii „Kubalonka” w Istebnej, Akta personalne W.Szredersa.

2. Centralne Archiwum Wojskowe, AP-9103.

3. Główna Biblioteka Lekarska w Warszawie, KOL W. Szreders.

Wykaz literatury:

1. $\quad$ Englert J. L., Domar Domaradzki A., Szkoła Podchorażych Sanitarnych 1922-1939, Londyn 1997.

2. Felchner A., Pod znakiem Eskulapa i Marsa. Stużba Zdrowia Wojska Polskiego (od jesieni 1918 r. do mobilizacji w 1939 r.), Oświęcim 2016.

3. Гладких П. Ф., Медицинская служба русской армии в русско-японской войне 1904-1905 г2., „Медикобиологические и социально-психологические проблемы безопасности в чрезвычайных ситуациях", 2016, n 3, s. 5-17.

4. Grzelak W., Wędrówki wodne, „Wiarus”, 1933, r. IV, nr 17, s. 373-374.

5. Kierzek A., Uzdrowiska nadniemeńskie dawniej, Wrocław 2017.

6. Kopociński K., Kopociński Z., Zarys organizacji i działalności 9. Szpitala Okręgowego w Brześciu nad Bugiem w latach 1920-1939, „Archiwum Historii i Filozofii Medycyny”, 2010, t. 73, s. 46-48. 
7. Kopociński K., Kopociński Z., Jeśman Cz., Sanatorium Rehabilitacyjne Leczenia Zeza w Sobótce, Żary 2016.

8. Kopociński Z., Zarys historii Wojskowego Szpitala Sezonowego w Druskiennikach, „Lekarz Wojskowy”, 2004, t. 80, nr 4, s. 280-281.

9. Kopociński Z., Kopociński K., Jeśman Cz., Płk dr Jan Józef Krusiewicz (1873-1930) - twórca i pierwszy komendant 9. Szpitala Okręgowego w Brześciu nad Bugiem, „Lekarz Wojskowy”, 2016, t. 94, nr 4, s. 456460.

10. Kopociński Z., Kopociński K., Jeśman Cz., 75. rocznica likwidacji 3. Szpitala Okręgowego w Grodnie-zarys historii powstania i rozwoju, „Lekarz Wojskowy”, 2015, t. 93, nr 1, s. 129-134.

11. Magowska A., Życie codzienne polskich lekarzy w stużbie Rosji w XIX w. w świetle ich listów, „Kwartalnik Historii Kultury Materialnej", 2013, R. 61, nr 3, s. 423-434.

12. Mały rocznik statystyczny 1939 r., pod red. S. Szulc, Warszawa 1939.

13. Michejda K., Wspomnienia chirurga, Kraków 1986.

14. Początki dziatalności sportowej, „Sport Wodny", 1930, r. 6, nr 3, s. 45, 86-87.

15. Podchorążowie z Ujazdowa. Wspomnienia Szkoły Podchorą̇ych Sanitarnych. W 50-ta rocznice założenia Szkoty, opr. B. Markowski, Londyn 1972.

16. Rocznik oficerski 1924, Warszawa 1924.

17. Rocznik oficerski 1928, Warszawa 1928.

18. Rocznik oficerski 1932, Warszawa 1932.

19. Sienkiewicz H., Potop, Wrocław-Warszawa-Kraków 1991.

20. Szarejko P., Stownik lekarzy polskich XIX wieku, Warszawa 1997, t. IV.

21. Wojskowy Klub Wioślarski „Niemen” w Grodnie, „Wioślarz Polski”, 1925, r. 1, nr 2, s. 54-55.

22. Z Grodna do Warszawy todziq sportowa. Wycieczka wojskowego Klubu Wioślarskiego "Niemen”, „Polska Zbrojna", 1923, r. III, nr 208, s. 4.

23. Z Wojskowego Klubu Wioślarskiego "Grodno", „Sport Wodny”, 1928, r.4, nr 3, s. 47.

\section{Wykaz stron internetowych:}

1. Белые Корабли <https://titanicanatomy.wordpress.com/2016/12/07/ белые-корабли-госпи тальные-суд> dostęp z 4 luty 2018.

2. Классные медицинские чины Черноморского Флота <http:www.wap.kortic.borda.ru/?1-17-9000000022-000-10001-0>, dostęp z 4 luty 2018 r. 